\title{
Social Media in Learning of Islamic Religion
}

\author{
Husen Hasan Basri, Muhamad Murtadlo \\ \{hahabe1976@gmail.com; murtadlo@kemenag.go.id\} \\ Agency of Religious Research and Development, Education and Training, \\ The Ministry of Religious Affairs
}

\begin{abstract}
The emergence of social media have an impact on changes in Islamic religious and religious learning methods, as well as these influences on the ethical maturity of its users in mass media and social media. Religious functionaries (Islamic religious education teachers in schools, madrasa teachers, religious lecturers, religious instructors, headmasters, and religious teachers in the religious education environment) utilize learning resources and facilities that come from mass media and social media. Using the survey method of 1031 Islamic religious functionaries, it was concluded that the mass media and social media became important facilities and facilities for religious functionaries in studying and teaching Islam. Social media is more desirable than mass media for the learning of religion and Islam.
\end{abstract}

Keywords: Role, Social Media, Religious learning

\section{Introduction}

The development of technology of social information has changed many things, including changing the style and tradition of Islamic religious and religious learning methods and strategies. The traditional method of Islamic learning places the teacher and literature (books/books) on religious references as the basic referential source for Islamic religious learning.

Lately, the effect of the development of information and communication technology is a shift from the role of the teacher (Ustadz), learning media or learning materials (book-based, yellow book), as a source of learning to newer media such as mass media and social media. There is new media authority as a source of religious and religious learning. That is, there is the use of mass media and social media in religious and religious learning [1].

The development of this new media, from traditional media (old, old fashion, mass media) to social media, has been marked by the emergence of media using networking and virtual communities that are worldwide and have created a borderless world. With social media, there has been a social networking site that has formed and allows users to connect, for example. Examples of social networking sites are Facebook, Myspace, Instagram, Path, Line, WhatsApp, Google, and so on. Mass media and social media can be alternative and substitutive sources that provide information, and can also be a tool or intermediary [2].

At present, Islamic religious education teachers in schools, madrasa teachers, religious lecturers, religious instructors, headmasters, and religious teachers in the religious education environment, many utilize mass media and social media facilities to assist the process of 
religious learning. Those identified above can also be referred to as spokesmen for Islamic religious and religious messages, or as religious functionaries. The religious functionary has a bargaining position and an important role in the implementation of contemporary Islamic religious and religious learning at a time when many people with practical choices and with a pragmatic spirit choose an easy medium of Islamic learning without being tied to traditional learning resources. Nowadays, people easily get Islamic teaching materials that are already available on social media [3].

Who are the providers of these Islamic teaching materials? Who are the users? Are the users of Islamic teaching materials on social media quite selective in choosing the provider sites and the materials they need? Do the providers of Islamic teaching materials have adequate knowledge and insight as an ethical basis for becoming providers of Islamic teaching materials? Who and what Islamic teaching materials are most interested in social media users in learning and teaching Islam? What methods and strategies for delivering Islamic teaching materials tend to be favored by social media users to study Islam? These are just several interesting questions to be examined especially for identifying and mapping issues of contemporary Islamic religious and religious learning about the use of mass media and social media. The answers to some of the questions above are very important, especially to be used as a basis for making public policies for the study of religion and Islamic religion that are relevant to current challenges, demands, and needs.

The issue of the use of mass media and social media above is the focus of this research. The main problem of this research is the interception of Islamic religious and religious learning by the use of mass media and social media. The main question of this research is what and how is the role of mass media and social media in Islamic religious and religious learning. The scope of this study are: first, the use of media in the study of religion and Islamic religion. Second, the use of information about the material and methods that can be used as a reference for learning and teaching Islam. Third, the attitude towards the media message content.

Several concepts in this study are defined. First, the role is a set of behavior expected by others towards someone according to their position in a system. The role is influenced by social conditions, both from within and from outside the culprit, and is stable. The concept of role can also be juxtaposed with one's social function or the instrumental function of a tool. A tool is considered to play a role when it is used by its users according to their basic functions.

Second, mass media and social media are defined as tools and platforms for communicating more massively and interactively. The difference between the two lies in the interaction model of information providers and information users. Mass media only serves unidirectional communication, while social media can bridge interactive communication between the two. The distinctive character of the two media has implications for the nature of the message, and the motives of the users of both media. The quality of messages in mass media is becoming more believable, on the other hand, because of the ambiguity of contributors, the quality of messages on social media is often unclear and invalid. As a result, the term hadith alifki, hoax, is better known on social media.

\section{Literature review}

Some previous studies on the use of social media in religious learning in educational institutions. First, the study of the use of Youtube entitled "Kredibiliti Youtube Sebagai Medium Pembelajaran Agama Dalam Peradaban Islam Kontemporer ". This study states that the abundant flow of information through YouTube has raised the issue of credibility of information 
content received by users. Qualitative method is through literature study and review through reference materials used in this study [5].

Secondly, the topic regarding the use of Instagram titled " Fenomena Penggunaan Media Sosial Instagram Sebagai Komunikasi Pembelajaran Agama Islam Oleh Mahasiswa Fisip Universitas Riau." This study concludes the use of Instagram, affection, and kinase or psychomotor instagram users in the community [4].

This study wants to map the use of social media not limited to Youtube and Instagram, but various other types of social media such as WhatsApp, Facebook, Line, Black Berry Messenger (BBM), Path, Twitter, Blog, and Kaskus.

\section{Research method}

This study uses a quantitative approach with a survey that is mapping in nature, namely to find out the role of mass media and social media in Islamic religious and religious learning. The subjects in this study were religious functionaries consisting of Islamic religious instructors, headmasters, madrasa education teachers, Islamic religious education teachers in schools, Islamic religious education teachers, and religious lecturers in 28 districts and cities spread across 14 provinces, namely: Cities Medan and Kab. Serdang District (North Sumatra), and Kota Padang.

Bukit Tinggi City (West Sumatra), Bandar Lampung City and Metro City (Lampung), Serang City and Cilegon City (Banten), Bandung City and Kab. Bandung (West Java), Semarang City and Surakarta City (Central Java), Surabaya City and Kab. Banyuwangi (East Java), Yogyakarta City and Regency. Sleman (DIY), Denpasar City and Kab. Jembrana (Bali), Mataram City and Kab. West Lombok (NTB), Pontianak City and Mempawah City (West Kalimantan), Banjarmasin City and Banjarbaru City (South Kalimantan), Makassar City and Kab. Gowa (South Sulawesi), Manado City and Bitung City (North Sulawesi).

Data collection was carried out in September 2017. The research data was collected using a questionnaire. The number of respondents in each target district/city was 37 people. Meanwhile, sampling is done in stages. First, the provincial and district/city samples were selected purposively. Second, the sample of respondents was selected non-randomly. The number of samples was 1031 people. The number of samples and the proportion of their distribution in each study area are the same, taking into account the balance of the sex distribution. However, because the study population is the majority of men, the sample of this study is also more male-dominated $(62 \%)$.

Determination of the sample selected by convention, namely sampling with consideration of convenience. This technique was chosen for several reasons. First, the nature of the sub-population is homogeneous. Secondly, the target population and sub-population are unknown, making it difficult to make sampling frames for field sampling. Third, this research is more as an exploratory study for the identification and mapping of trending and strategic issues in the use of mass media technology and social media for Islamic religious and religious learning. 


\section{Results and discussion}

\subsection{Profile of respondents}

The number of research samples was 1031 people. The mean age of respondents was 40.53 years with a Debian standard of 8.97 years with the median profile being aged between $36-45$ years; $82 \%$ had attended formal education at a religious educational institution. While the respondent's socio-religious status profile is as follows; $93.5 \%$ religious leaders, $75 \%$ administrators of places of worship, $52 \%$ administrators of Islamic educational institutions, $49 \%$ administrators of mass organizations and 45 administrators of Islamic political parties. The socio-religious role is as follows: $36 \%$ claim to regularly fill Friday sermons at least once per 3 months; $49 \%$ complete scheduled routine religious studies, and $20 \%$ admit they routinely provide religious consulting services at least once per 3 months.

In terms of the highest level of education completed, the respondents of this study were educated. This is evident from the fact that more than $88 \%$ of respondents have a minimum bachelor's degree. However, there are about $10 \%$ of the sample having a high school education or salaf education. Also, almost $90 \%$ of respondents are active users of social media.

\subsection{The use of media in Islamic religious learning}

Compared to social media, mass media tend to be no more used by respondents in the study of religion and religion of Islam. Grafik 1 shows that specifically, WhatsApp (WA) became the social media most frequently used by respondents, then followed by Facebook to learn and teach Islam. The rest, only less than $50 \%$ of respondents use other social media. 


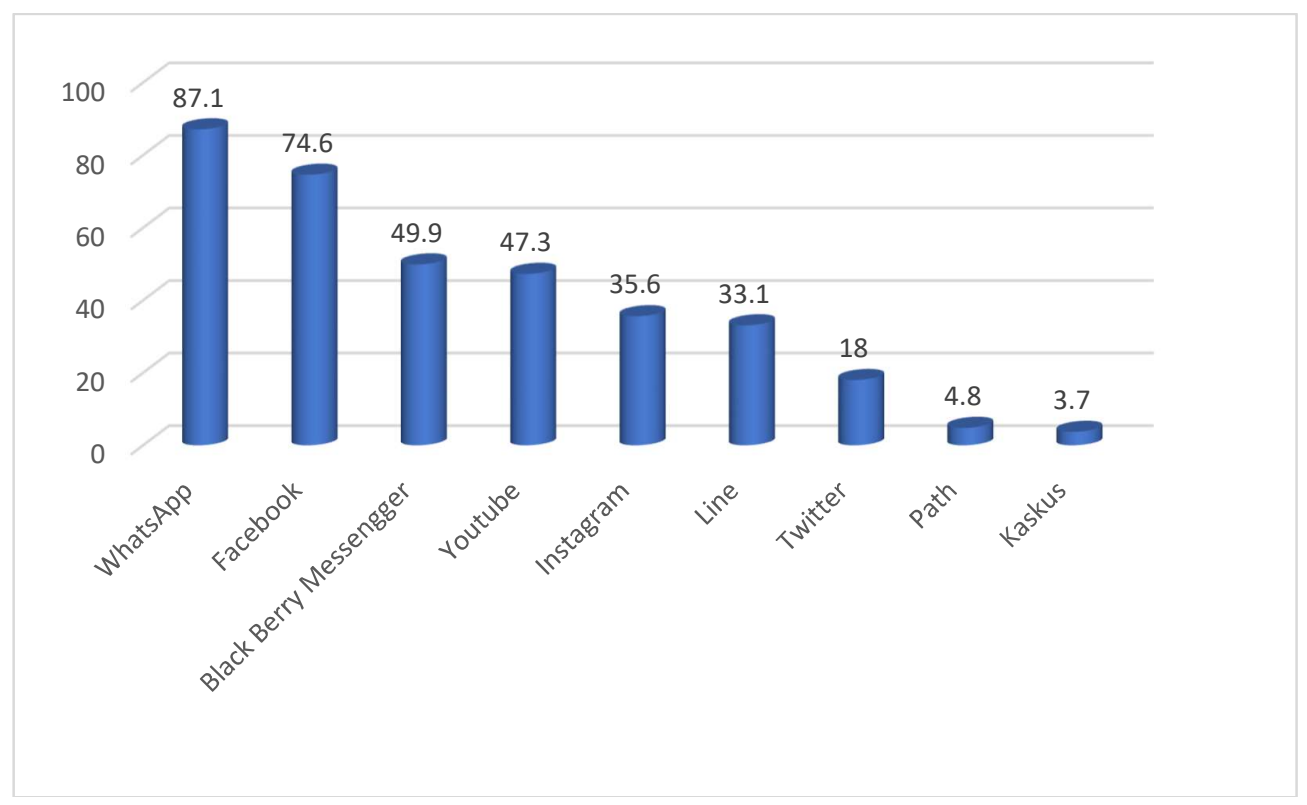

Fig.1. Social media trends used.

Not only that, WA aside from being the most dominant social media, WA users tend to feel it is enough with WA media alone, without using other social media. This can be seen in Table 1 which shows that a large number of WA users do not use other social media. Conversely, other social media users are also WA users.

Table 1. Map of users according to social media background ever used (\%).

\begin{tabular}{|c|c|c|c|c|c|c|c|c|}
\hline No & Type of Social Media & User Status & WA & Facebook & BBM & Youtube & Instagram & Line \\
\hline \multirow{2}{*}{1} & \multirow{2}{*}{ WhatsApp } & No & - & 26.3 & 8.3 & 10.5 & 6.8 & 6.8 \\
\hline & & Yes & . & 81.7 & 55.0 & 52.8 & 39.9 & 37.0 \\
\hline \multirow{2}{*}{2} & \multirow{2}{*}{ Facebook } & No & 62.3 & - & 11.8 & 18.3 & 6.9 & 9.5 \\
\hline & & Yes & 85.4 & - & 61.6 & 57.2 & 45.4 & 41.1 \\
\hline \multirow{2}{*}{3} & \multirow{2}{*}{ BBM } & No & 76.8 & 56.1 & - & 32.9 & 21.2 & 15.6 \\
\hline & & Yes & 97.8 & 93.9 & - & 62.4 & 51.6 & 51.3 \\
\hline \multirow{2}{*}{4} & \multirow{2}{*}{ Youtube } & No & 78.1 & 60.6 & 35.0 & - & 13.3 & 17.5 \\
\hline & & Yes & 97.1 & 90.2 & 64.5 & - & 58.8 & 50.4 \\
\hline \multirow[b]{2}{*}{5} & \multirow{2}{*}{ Instagram } & No & 81.3 & 63.3 & 31.3 & 35.5 & - & 18.4 \\
\hline & & Yes & 97.5 & 95.1 & 80.9 & 68.7 & - & 59.7 \\
\hline \multirow{2}{*}{6} & \multirow{2}{*}{ Line } & No & 82.0 & 65.7 & 35.7 & 35.1 & 21.4 & - \\
\hline & & & 97.1 & 92.7 & 76.1 & 72.1 & 64.2 & - \\
\hline
\end{tabular}


All social media are used to study Islam as shown in Graph 2. However, the frequency distribution of using social media to study Islam at least once a month varies as follows. WA remains the most dominant media for learning Islam, followed by Facebook. Commercial private television is still the foundation $(17.48 \%)$ as the mass media for learning Islam at least once a month by respondents. It is quite interesting that TV specifically broadcasting Islamic material is not yet very popular; only about $7.4 \%$ of respondents used to study Islam. Even special TV is no more desirable compared to other social media.

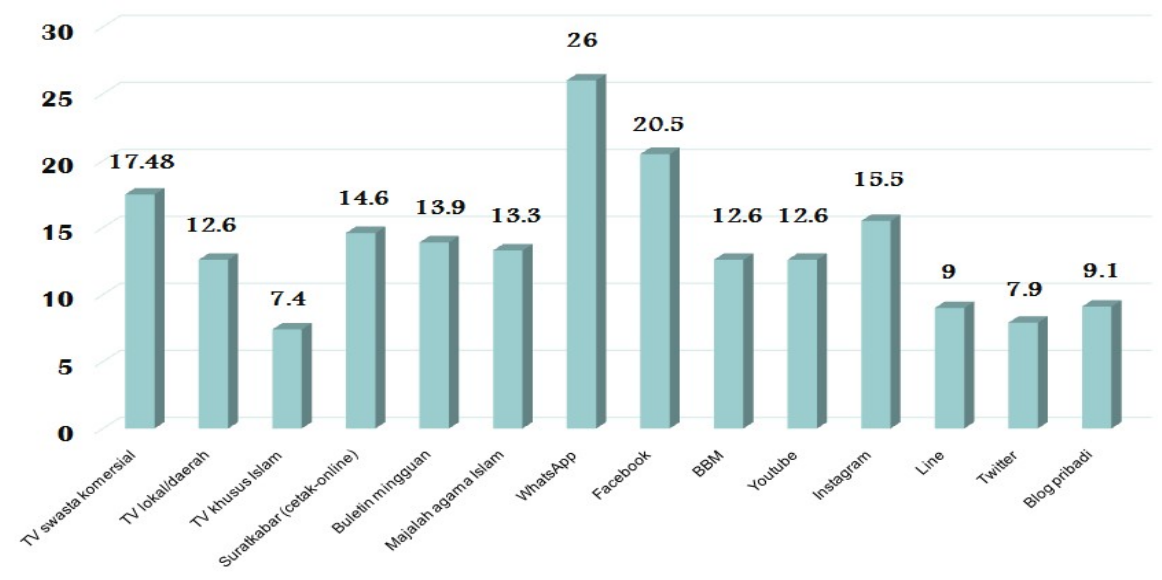

Fig. 2. Name of social media used at least once a month to study Islam.

Graph 3. shows the trend in the use of mass media and social media to teach Islam. Media WA (16.8\%) and Youtube (15.1\%) are still very dominant as an option to be used as a reference for teaching Islam at least once a month. Mass media (television) facilities are no longer the main trend used for teaching Islamic references. In other words, the role of old media transmission and transformation (old media) as a reference or source of Islamic teaching and learning, has been displaced by the presence of new social media [6]. 


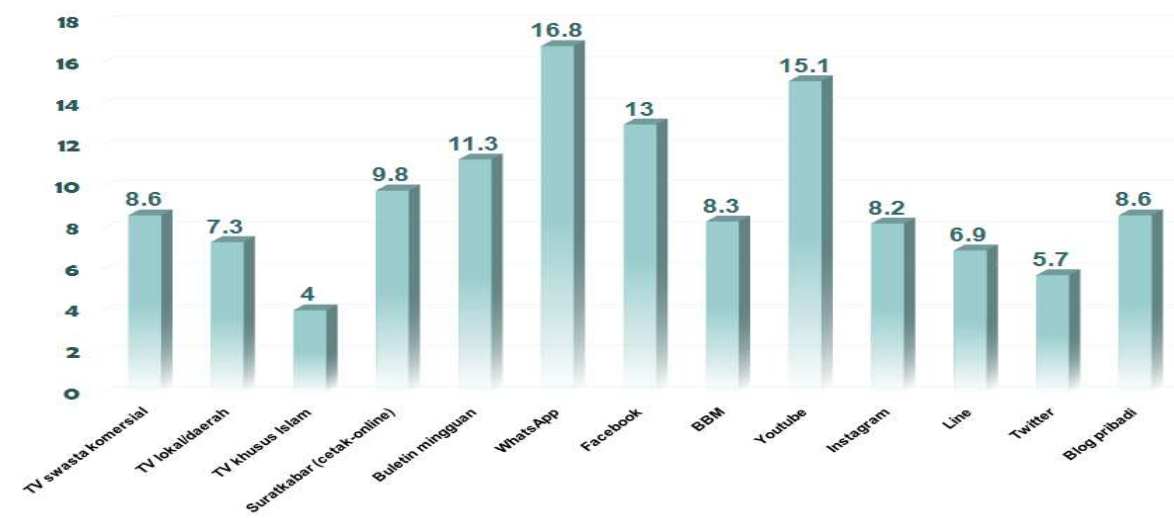

Fig. 3. Social media used minimal once a month to teach Islam.

\subsection{Use of information about material and methods}

The use of electronic media to become objects of learning or teaching Islam is relatively evenly distributed in all Islamic fields. Graph 4 shows that the majority (range 2/3) of respondents said they had never used mass-social media to search for Islamic material. Only in the range of $15-19 \%$ of respondents said that they use mass-social media to search for Islamic material at least twice a month, except in the economic and social fields of government. However, social-mass media tends to only be used to find the latest news about Islam. 


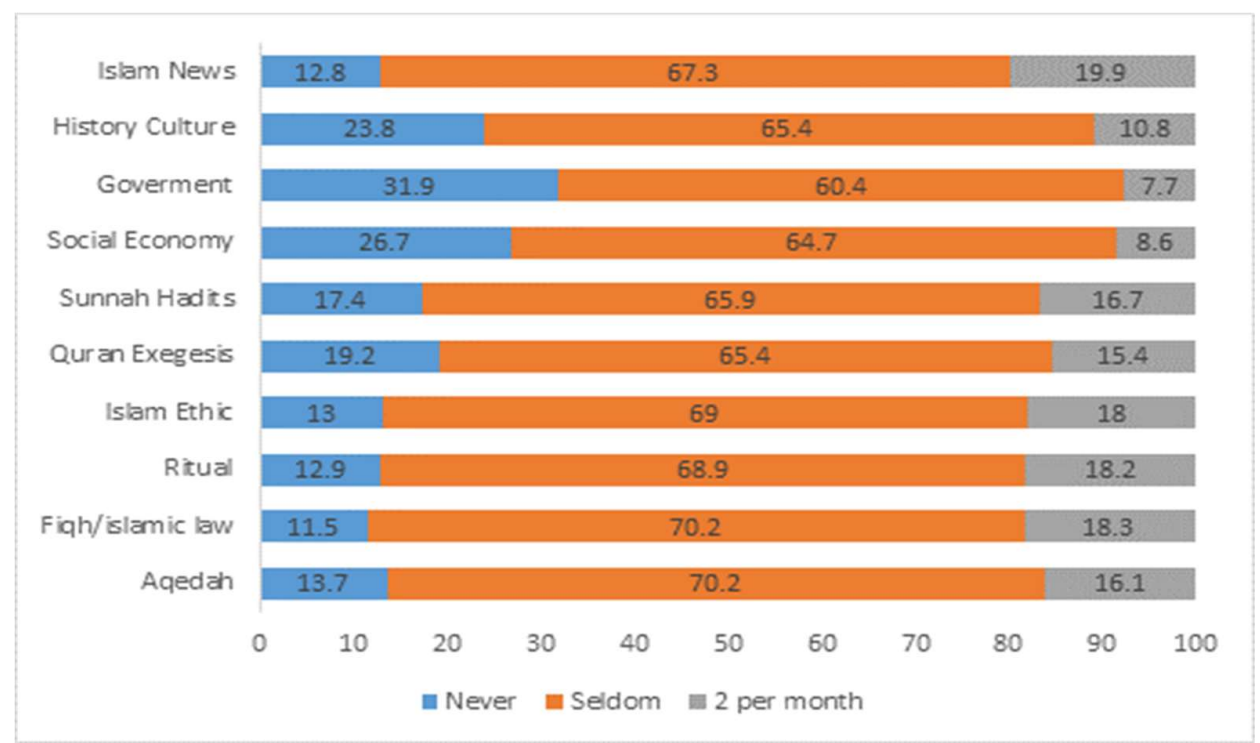

Fig. 4. The intensity of looking for Islamic material objects in the social media time to study.

What methods of delivering Islamic material are most likely to be interested in teaching and learning Islam? Graph 5 shows that the dialogue method is the most popular $(74.9 \%$ of respondents) in the process of learning religion and Islam. Traditional methods such as the textual method and lecture became less attractive to the respondents of this study. This data reinforces the tendency of educated people to like dialogical methods. On the other hand, this finding is another note that educated people tend not to like reading texts to study Islam.

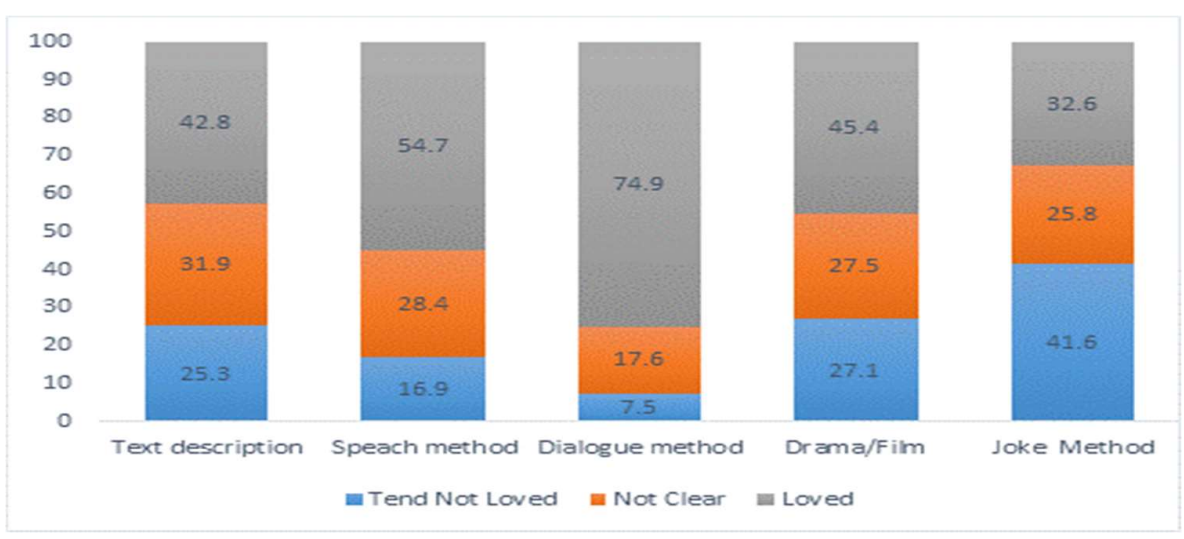

Fig. 5. The method of delivering the liked message to teach Islam. 


\subsection{Attitude to media message contents}

Ease of accessing media for the process of learning religion and Islam. Respondents considered easy access to mass media and social media for the process of learning religion and Islamic religion. WhatsApp ranks first $(65.2 \%)$ as easily accessible social media to get Islamic religious material, followed by Youtube and Facebook. Whereas Path media as media that is not easily accessible to obtain Islamic religious material.

Table 2. Assessment of the ease of accessing social media forget Islamic religious material.

\begin{tabular}{llllll}
\hline No & Type of Social Media & Not Easy & Quite Easy & Easy & Valid Answer \\
\hline 1 & WhatsApp & 10.8 & 24.0 & 65.2 & 846 \\
2 & Facebook & 11.9 & 30.2 & 57.8 & 721 \\
3 & Black Berry Messengger & 28.5 & 28.5 & 43.0 & 456 \\
4 & Youtube & 10.7 & 26.2 & 63.2 & 478 \\
5 & Instagram & 29.9 & 27.6 & 42.5 & 690 \\
6 & Line & 34.0 & 25.6 & 40.5 & 722 \\
7 & Twitter & 40.8 & 19.5 & 39.7 & 174 \\
8 & Path & 51.1 & 21.3 & 27.7 & 984 \\
\hline
\end{tabular}

What about the completeness of reading texts, watching videos and listening to audio recordings of Islamic religious material obtained from social media. Table 3 illustrates only $17.9 \%$ for WhatsApp, $14.8 \%$ for Facebook, and $12.7 \%$ for Youtube that is "always complete" reading religious texts on social media for themselves. However, as much as $7.5 \%$ for WhatsApp, 8.6\% for Facebook, and 12\% for YouTube that "never completely" reads the text of religious material on social media for themselves.

Table 3. Intensity completeness in reading text of religious materialon social media for yourself.

\begin{tabular}{llllllll}
\hline No & $\begin{array}{l}\text { Type of Social } \\
\text { Media }\end{array}$ & $\begin{array}{l}\text { Never } \\
\text { complete }\end{array}$ & $\begin{array}{l}\text { rarely } \\
\text { complete }\end{array}$ & $\begin{array}{l}\text { Sometimes } \\
\text { complete }\end{array}$ & $\begin{array}{l}\text { often } \\
\text { complete }\end{array}$ & $\begin{array}{l}\text { Always } \\
\text { complete }\end{array}$ & $\begin{array}{l}\text { valid } \\
\text { Answer }\end{array}$ \\
\hline 1 & WhatsApp & 7.5 & 11.8 & 29.7 & 33.0 & 17.9 & 837 \\
2 & Facebook & 8.6 & 17.0 & 33.0 & 26.6 & 14.8 & 335 \\
3 & BBM & - & - & - & - & - & - \\
4 & Youtube & 12.0 & 19.7 & 31.1 & 24.5 & 12.7 & 441 \\
5 & Instagram & 20.2 & 22.1 & 15.2 & 22.4 & 10.0 & 321 \\
6 & Line & 24.7 & 21.5 & 25.3 & 18.8 & 9.7 & 288 \\
7 & Twitter & 30.6 & 21.2 & 22.4 & 12.9 & 12.9 & 170 \\
8 & Path & 25.6 & 20.9 & 37.2 & 7.0 & 9.3 & 43 \\
\hline
\end{tabular}

What about the completeness of reading texts, watching videos and listening to audio recordings of Islamic religious material obtained from social media. Table 3 illustrates only 
$17.9 \%$ for WhatsApp, $14.8 \%$ for Facebook, and $12.7 \%$ for Youtube that is "always complete" reading religious texts on social media for themselves. However, as much as $7.5 \%$ for WhatsApp, $8.6 \%$ for Facebook, and 12\% for YouTube that "never completely" read the text of religious material on social media for themselves.

Table 4. Intensity completeness in reading text of islamic material before sharing on social media.

\begin{tabular}{llllllll}
\hline No & $\begin{array}{c}\text { Type of } \\
\text { Social } \\
\text { Media }\end{array}$ & $\begin{array}{c}\text { Never } \\
\text { complete }\end{array}$ & $\begin{array}{c}\text { rarely } \\
\text { complete }\end{array}$ & $\begin{array}{c}\text { Sometimes } \\
\text { complete }\end{array}$ & $\begin{array}{c}\text { often } \\
\text { complete }\end{array}$ & $\begin{array}{c}\text { Always } \\
\text { complete }\end{array}$ & $\begin{array}{c}\text { valid } \\
\text { Answer }\end{array}$ \\
\hline 1 & WhatsApp & 7.1 & 11.1 & 21.4 & 28.1 & 32.3 & 832 \\
2 & Facebook & 11.6 & 14.2 & 23.6 & 22.9 & 27.7 & 690 \\
3 & BBM & - & - & - & - & - & - \\
4 & Youtube & - & - & - & - & - & - \\
5 & Instagram & 28.5 & 14.2 & 19.7 & 18.8 & 18.8 & 309 \\
6 & Line & 27.9 & 18.1 & 19.9 & 15.9 & 18.4 & 277 \\
7 & Twitter & 28.8 & 18.6 & 20.5 & 10.9 & 21.2 & 156 \\
8 & Path & 30.2 & 25.6 & 20.9 & 9.3 & 14.0 & 43 \\
\hline
\end{tabular}

Furthermore, completeness watching religious material videos. Table 5 illustrates only 21.7\% for WhatsApp, 15.1\% for Facebook, and 21.4\% for Youtube who "always finish" watching videos of religious material on social media for themselves. However, as much as $8.2 \%$ for WhatsApp, 10.7\% for Facebook, and 5.5\% for YouTube that "never finish" watching videos of religious material on social media for themselves.

Table 5. Mastery intensity watching video material for religion on social media for yourself.

\begin{tabular}{llllllll}
\hline No & $\begin{array}{l}\text { Type } \\
\text { Social } \\
\text { Media }\end{array}$ & $\begin{array}{l}\text { Never } \\
\text { complete }\end{array}$ & $\begin{array}{l}\text { rarely } \\
\text { complete }\end{array}$ & $\begin{array}{l}\text { Sometimes } \\
\text { complete }\end{array}$ & $\begin{array}{l}\text { often } \\
\text { complete }\end{array}$ & $\begin{array}{l}\text { Always } \\
\text { complete }\end{array}$ & $\begin{array}{l}\text { valid } \\
\text { Answer }\end{array}$ \\
\hline 1 & WhatsApp & 8.2 & 11.3 & 29.6 & 29.3 & 21.7 & 844 \\
2 & Facebook & 10.7 & 17.8 & 32.7 & 23.9 & 15.1 & 704 \\
3 & Youtube & 5.5 & 15.1 & 31.4 & 26.5 & 21.4 & 560 \\
4 & Instagram & 26.5 & 17.5 & 22.6 & 20.8 & 12.7 & 332 \\
5 & Line & 33.0 & 20.0 & 22.0 & 16.3 & 8.7 & 300 \\
6 & Twitter & 31.2 & 20.0 & 26.5 & 14.7 & 7.6 & 861 \\
7 & Path & 32.6 & 30.4 & 21.7 & 8.7 & 6.5 & 46 \\
\hline
\end{tabular}

What about the intensity of completeness reading the text of religious material before it is distributed on social media. Table 4 illustrates only $32.3 \%$ for WhatsApp, $27.7 \%$ for Facebook, and $21.2 \%$ for Twitter that "always completely" reads the text of religious material before it is shared on social media. However, as much as $7.1 \%$ for WhatsApp, $11.6 \%$ for Facebook, and $28.8 \%$ for Twitter that "never completely" read the text of religious material before it is shared on social media. 
Table 6. Mastery intensity watching video material for religion before being shared on social media.

\begin{tabular}{llllllll}
\hline No & $\begin{array}{l}\text { Type } \\
\text { Social } \\
\text { Media }\end{array}$ & $\begin{array}{l}\text { Never } \\
\text { complete }\end{array}$ & $\begin{array}{l}\text { rarely } \\
\text { complete }\end{array}$ & $\begin{array}{l}\text { Sometimes } \\
\text { complete }\end{array}$ & $\begin{array}{l}\text { often } \\
\text { complete }\end{array}$ & $\begin{array}{l}\text { Always } \\
\text { complete }\end{array}$ & $\begin{array}{l}\text { valid } \\
\text { Answer }\end{array}$ \\
\hline 1 & WhatsApp & 7.6 & 9.3 & 20.5 & 30.6 & 32.0 & 826 \\
2 & Facebook & 11.8 & 13.8 & 23.4 & 23.7 & 27.4 & 654 \\
3 & Youtube & 12.3 & 12.5 & 20.7 & 24.8 & 29.6 & 439 \\
4 & Instagram & 25.8 & 14.4 & 17.3 & 19.6 & 22.9 & 3.6 \\
5 & Line & 28.8 & 14.0 & 18.8 & 19.6 & 18.8 & 271 \\
6 & Twitter & 28.2 & 19.9 & 17.3 & 12.8 & 21.8 & 156 \\
7 & Path & 32.6 & 18.6 & 25.6 & 11.6 & 11.6 & 43 \\
\hline
\end{tabular}

Furthermore, completeness listening to audio recordings of Islamic religious material obtained from social media. Table 7 illustrates only 15\% for WhatsApp, 10\% for Facebook, and $13.9 \%$ for Youtube that is "always complete" listening to recorded religious material on social media for themselves. However, as much as 9.2\% for WhatsApp, 12.7\% for Facebook, and 9.4\% for YouTube that "never completely" listened to recorded religious material on social media.

Table 7. Intensity of listening completeness sound recordings of religious material on social media for yourself.

\begin{tabular}{llllllll}
\hline No & $\begin{array}{l}\text { Type } \\
\text { Social } \\
\text { Media }\end{array}$ & $\begin{array}{l}\text { Never } \\
\text { complete }\end{array}$ & $\begin{array}{l}\text { rarely } \\
\text { complete }\end{array}$ & $\begin{array}{l}\text { Sometimes } \\
\text { complete }\end{array}$ & $\begin{array}{l}\text { often } \\
\text { complete }\end{array}$ & $\begin{array}{l}\text { Always } \\
\text { complete }\end{array}$ & $\begin{array}{l}\text { valid } \\
\text { Answer }\end{array}$ \\
\hline 1 & WhatsApp & 9.2 & 17.2 & 30.4 & 28.2 & 15.0 & 819 \\
2 & Facebook & 12.7 & 23.0 & 31.8 & 22.5 & 10.0 & 679 \\
3 & Youtube & 9.4 & 17.9 & 31.8 & 27.0 & 13.9 & 459 \\
4 & Instagram & 27.7 & 22.1 & 21.2 & 21.5 & 7.5 & 321 \\
5 & Line & 30.4 & 24.2 & 22.2 & 17.1 & 6.1 & 293 \\
6 & Twitter & 33.3 & 22.6 & 26.2 & 9.5 & 8.3 & 168 \\
7 & Path & 28.3 & 23.9 & 30.4 & 6.5 & 10.9 & 46 \\
\hline
\end{tabular}

Then complete listening to audio recordings of Islamic religious material before being distributed on social media. Table 8 illustrates only $28.5 \%$ for WhatsApp, $24.1 \%$ for Facebook, and $24.3 \%$ for Youtube that is "always complete" listening to recordings of Islamic religious material before it is shared on social media. However, as much as $9 \%$ for WhatsApp, $16.8 \%$ for Facebook, and $15.3 \%$ for YouTube that "never completely" listens to the recorded sound of religious material before it is shared on social media. 
Table 8. Intensity to listening completeness

voice recordings of religious material before distributed on social media.

\begin{tabular}{llllllll}
\hline No & $\begin{array}{l}\text { Type } \\
\text { Social } \\
\text { Media }\end{array}$ & $\begin{array}{l}\text { Never } \\
\text { complete }\end{array}$ & $\begin{array}{l}\text { rarely } \\
\text { complete }\end{array}$ & $\begin{array}{l}\text { Sometimes } \\
\text { complete }\end{array}$ & $\begin{array}{l}\text { often } \\
\text { complete }\end{array}$ & $\begin{array}{l}\text { Always } \\
\text { complete }\end{array}$ & $\begin{array}{l}\text { valid } \\
\text { Answer }\end{array}$ \\
\hline 1 & WhatsApp & 9.0 & 11.1 & 22.2 & 29.3 & 28.5 & 793 \\
2 & Facebook & 16.8 & 15.0 & 21.6 & 22.4 & 24.1 & 638 \\
3 & Youtube & 15.3 & 13.9 & 21.1 & 25.5 & 24.3 & 432 \\
4 & Instagram & 29.6 & 15.9 & 17.6 & 17.6 & 19.3 & 301 \\
5 & Line & 30.8 & 13.9 & 19.5 & 15.0 & 20.7 & 266 \\
6 & Twitter & 29.4 & 17.6 & 19.0 & 12.4 & 21.6 & 153 \\
7 & Path & 34.9 & 16.3 & 18.6 & 14.0 & 16.3 & 43 \\
\hline
\end{tabular}

How the level of trust in the truth of Islamic religious material on social media can be seen in Table 9. Is $48.1 \%$ of respondents WhatsApp, Youtube $(45.6 \%)$, Facebook $(45.2 \%)$, Instagram (40.6\%), and line $(40.5 \%)$ who claimed to be "quite trusted" with the truth of the contents of religious material on social media. Meanwhile, in the range of $30 \%$ to $54 \%$ of respondents claimed to at least lack faith in the truth of religious material on social media. This is a paradoxical phenomenon from the findings of this study. On the one hand, respondents like to share religious material from social media to their friends, while on the other hand, respondents tend to lack confidence in the religious material that he shares.

Table 9. Level of trust in truth Islamic religious material on social media.

\begin{tabular}{llllllll}
\hline No & $\begin{array}{l}\text { Type of } \\
\text { Media }\end{array}$ & $\begin{array}{l}\text { No } \\
\text { trust }\end{array}$ & $\begin{array}{l}\text { Lack } \\
\text { trust }\end{array}$ & $\begin{array}{l}\text { onough } \\
\text { trust }\end{array}$ & Trust & $\begin{array}{l}\text { Strongly } \\
\text { trust }\end{array}$ & $\begin{array}{l}\text { Valid } \\
\text { Answer }\end{array}$ \\
\hline 1 & WhatsApp & 3.2 & 26.5 & 48.1 & 20.1 & 2.0 & 837 \\
2 & Facebook & 3.8 & 35.3 & 45.2 & 14.2 & 1.4 & 703 \\
3 & BBM & 11.5 & 44.2 & 35.0 & 9.0 & 0.2 & 443 \\
4 & Youtube & 1.7 & 29.3 & 45.6 & 21.2 & 2.1 & 471 \\
5 & Instagram & 11.9 & 34.3 & 40.6 & 11.9 & 1.3 & 318 \\
6 & Line & 14.0 & 29.8 & 40.5 & 15.4 & 0.3 & 299 \\
7 & Twitter & 13.5 & 39.4 & 37.6 & 8.8 & 0.6 & 170 \\
8 & Blog & 7.5 & 31.7 & 41.7 & 19.2 & - & 120 \\
\hline
\end{tabular}

The intensity of checking the truth of Islamic religious material on social media can be seen in Table 10. Only 15, 8\% for WhatsApp, 15.8\% for Facebook, 16, 9\% for YouTube from respondents who tend to check the truth of Islamic religious material that he got from the media social. The rest, respondents tend to be less concerned about the truth of religious material that they get from social media. 
Table 10. Intensity checking the truth of Islamic religious material on social media.

\begin{tabular}{llllllll}
\hline No & $\begin{array}{l}\text { Type of Social } \\
\text { Media }\end{array}$ & $\begin{array}{l}\text { Never } \\
\text { Chek }\end{array}$ & $\begin{array}{l}\text { Rarely } \\
\text { Chek }\end{array}$ & $\begin{array}{l}\text { Sometimes } \\
\text { Chek }\end{array}$ & $\begin{array}{l}\text { Often } \\
\text { Chek }\end{array}$ & $\begin{array}{l}\text { Always } \\
\text { Chek }\end{array}$ & $\begin{array}{l}\text { Valid } \\
\text { Answer }\end{array}$ \\
\hline 1 & WhatsApp & 9.7 & 16.4 & 34.9 & 23.3 & 15.8 & 849 \\
2 & Facebook & 11.1 & 19.7 & 32.7 & 20.7 & 15.8 & 704 \\
3 & BBM & 21.7 & 22.4 & 28.0 & 15.7 & 12.3 & 447 \\
4 & Youtube & 9.5 & 18.6 & 33.1 & 21.8 & 16.9 & 472 \\
5 & Instagram & 23.3 & 17.6 & 27.9 & 17.3 & 13.9 & 330 \\
6 & Line & 23.1 & 21.1 & 28.8 & 15.4 & 11.7 & 299 \\
7 & Twitter & 20.2 & 19.0 & 32.7 & 13.7 & 14.3 & 168 \\
8 & Blog & 11.3 & 19.4 & 33.1 & 23.4 & 12.9 & 124 \\
\hline
\end{tabular}

\section{Conclusions}

From the above data description, the study concludes: first, mass and social media are important facilities and facilities for religious functionaries in studying and teaching Islam. Social media is more desirable than mass media for the learning of religion and Islam. Second, the role of the old media (mass media) has been shifted by new media (social media) for religious communication in the process of learning religion and Islamic religion. Even special TV that specifically broadcasts Islamic religious material has not yet gained a place in the hearts of research respondents. Third, the WA media, Facebook and Youtube are the most popular choices among respondents for the Islamic learning process. Fourth, there is an interesting phenomenon about the way respondents treat mass media and social media. The majority of respondents did not finish watching the video and also heard recordings of Islamic material that they got before being distributed to friends. This phenomenon is not in line with the facts about the spirit of a tendency to want to share which is raised among respondents.

There are several recommendations from the results of the study. First. religious policymakers in the Ministry of Religion, religious institutions and religious organizations, need to prepare religious modules as propaganda material that is more varied and can be accounted for on social media, which in turn can be a counter-discourse (comparison) of the materials negative religion circulates in the media. Second, religious functionaries should optimize the use of mass media and social media for religious and religious learning. Third, religious functionaries need to be more creative and innovative in presenting religious material in mass media and social media. Fourth, all social media users need to strictly select the information that they will share with friends on social media networks.

\section{References}

[1] Bandura, A. 1977. Social Learning Theory. Englewood Cliffs, NJ: Prentice Hall

[2] Hergenhahn, B.R \& Olson, Mattew. 2012.. Theories Of Learning. Jakarta: Kencana Prenada Media Group 
[3] Kurniasih, Eko. 2006. "Hubungan Antara Perilaku Menonton Tayangan Sinetron Religius dengan Sikap Remaja terhadap Agama Islam." Skripsi Program Studi Komunikasi dan Pengembangan Masyarakat, Fakultas Pertanian Institut Pertanian Bogor.

[4] Sari, M. P. (2017) 'Fenomena Penggunaan Media Sosial Instagram Sebagai Komunikasi Pembelajaran Agama Islam Oleh Mahasiswa Fisip Universitas Riau', JOM FISIP, 4(2), pp. 1-13.

[5] Siti Rokiah Ab Rahman and Adam, F. (2015) 'Kredibiliti Youtube Sebagai Medium Pembelajaran Agama Dalam Peradaban Islam Kontemporari', in International Conference on Empowering Islamic Civilization in the 21st Century, pp. 593-599.

[6] Wahyudianata, Megawati (2007). "Televisi dan Pergeseran Konsep Seks Normatif: Pengaruh Tayangan Pornomedia Televisi dan Agama Terhadap Sikap Seks Mahasiswa S1 Kota Surabaya." Scriptura 1.1. 